Artikel Penelitian

\title{
Analisis Kandungan Gizi, Nilai Energi, dan Uji Organoleptik Cookies Tepung Beras dengan Substitusi Tepung Sukun
}

Nutrient Content Analysis, Energy Value, and Organoleptic Test of Rice Flour Cookies with Breadfruit Flour Substitution

Fauzia Kusuma Wulandari, Bhakti Etza Setiani, Siti Susanti

Program Studi Teknologi Pangan, Fakultas Peternakan dan Pertanian, Universitas Diponegoro, Semarang

"Korespondensi dengan penulis (fwulandari62@gmail.com)

Artikel ini dikirim pada tanggal 12 Mei 2016 dan dinyatakan diterima tanggal 01 Oktober 2016. Artikel ini juga dipublikasi secara online melalui www.jatp.ift.or.id. Hak cipta dilindungi undang-undang. Dilarang diperbanyak untuk tujuan komersial.

Diproduksi oleh Indonesian Food Technologists® (C2016

\begin{abstract}
Abstrak
Penelitian cookies tepung beras yang disubstitusi dengan tepung sukun dilakukan untuk mengeksplorasi karakteristik dari kandungan gizi, nilai energi, dan uji organoleptik yang dihasilkan oleh cookies. Parameter yang diamati dalam penelitian ini adalah kadar air, kadar protein, kadar lemak, kadar karbohidrat, kadar abu, kadar serat kasar, nilai energi, dan organoleptik. Penelitian ini dilakukan dengan desain penelitian Rancangan Acak Lengkap (RAL) dengan 6 perlakuan dan 3 kali ulangan dengan mensubstitusi bahan baku tepung. Hasil penelitian menunjukkan bahwa kadar air terendah pada konsentrasi $10 \%$ dan $50 \%$, kadar protein terendah pada konsentrasi $50 \%$, kadar lemak terendah pada konsentrasi 0\%, kadar karbohidrat terendah pada konsentrasi 30\%, kadar abu terendah pada konsentrasi $0 \%$, kadar serat kasar terendah pada konsentrasi $0 \%$, dan nilai energi terendah pada konsentrasi $30 \%$. Uji organoleptik kesukaan yang paling disukai oleh panelis adalah cookies dengan konsentrasi $0 \%$. Semakin besar konsentrasi substitusi tepung sukun menurunkan kesukaan secara keseluruhan terhadap cookies tepung beras dengan substitusi tepung sukun yang dihasilkan.
\end{abstract}

Kata kunci: cookies, tepung sukun, tepung beras

\begin{abstract}
A study of cookies made from rice flour shich substituted by breadfruit flour was conducted. The objective of this study was to explore the characteristic of the nutrient, energy value, and also consumer preferences, using organoleptic test. The water, protein, fat, carbohydrate, ash, and crude fiber content were observed as nutrient value of cookies. Another parameters suchas energy value and organoleptic test were also observed. Completely Randomized Design (CRD) with 6 treatments and 3 replications were used as research design. The results showed that the lowest water content levels at $10 \%$ and $50 \%$ of concentrations, the lowest protein content levels at $50 \%$ of concentrations, the lowest fat content levels at $0 \%$ of concentrations, the lowest carbohydrate content levels at $30 \%$ of concentrations, the lowest ash content at $0 \%$ of concentrations. The lowest crude fiber content at $0 \%$ of concentrations, and the lowest energy value at $30 \%$ of concentrations. The organoleptic tests which most preferred by the panelists were cookies with $0 \%$ concentrations. The higher concentration of breadfruit flour substitution implicate the lower of overall preferences of cookies made from rice flour which substituted with breadfruit flour.
\end{abstract}

Keywords: cookies, rice flour, breadfruit flour

\section{Pendahuluan}

Cookies merupakan salah satu jenis makanan ringan yang sangat digemari oleh masyarakat Indonesia karena memiliki rasa dan bentuk yang menarik. Bentuk dan rasa dari cookies sangat beragam tergantung bahan yang ditambahkan pada pembuatannya. Semakin banyak permintaan akan produk cookies, penggunaan bahan baku pembuatan cookies yaitu tepung terigu akan terus meningkat dan harga tepung terigu yang tersedia di pasaran juga semakin tinggi. Ketergantungan pada tepung terigu mengakibatkan meningkatnya jumlah impor untuk komoditas gandum tersebut. Menurut data Badan Pusat Statistik (2012) Indonesia merupakan negara pengimpor gandum dengan volume impor mencapai 6,3 juta ton. Oleh karena itu, perlu adanya upaya untuk mengurangi ketergantungan terhadap penggunaan tepung terigu yaitu dengan cara mengalihkan penggunaan terigu ke non terigu (Fatkurahman et al., 2012). Salah satu alternatif untuk menggantikan tepung terigu menjadi non terigu adalah memanfaatkan tepung lokal dalam produksi makanan sehingga dapat mengurangi ketergantungan terhadap bahan pangan impor. Cookies dapat diproduksi dengan menggunakan berbagai macam tepung termasuk tepung yang tidak mengandung gluten karena cookies tidak membutuhkan pengembangan (Gayati, 2014). Dengan demikian, pembuatan cookies dapat menggunakan tepung beras dan tepung sukun sebagai pengganti tepung terigu. Pemanfaatan tepung-tepung lokal seperti tepung beras dan tepung sukun sebagai bahan baku pembuatan cookies diharapkan dapat mengurangi ketergantungan masyarakat terhadap penggunaan tepung terigu dan meningkatkan potensi pangan lokal yang tersedia di Indonesia. 
Tabel 1. Skor penilaian uji organoleptik

\begin{tabular}{|c|c|c|c|c|c|}
\hline Rasa & Rasa Coklat & Warna & Aroma & Tekstur & Kesukaan \\
\hline $1=$ tidak manis & $1=$ tidak terasa & 1 = sangat coklat & $1=$ tidak harum & 1 = tidak renyah & 1 = tidak suka \\
\hline $2=$ agak manis & 2 = agak terasa & 2 = agak sangat coklat & 2 = agak harum & 2 = agak renyah & 2 = agak suka \\
\hline $3=$ manis & $3=$ terasa & $3=$ coklat & $3=$ harum & $3=$ renyah & $3=$ suka \\
\hline 4 = sangat manis & 4 = sangat terasa & 4 = coklat keemasan & 4 = sangat harum & 4 = sangat renyah & 4 = sangat suka \\
\hline
\end{tabular}

Tepung sukun merupakan produk olahan sukun yang diperoleh dari buah sukun yang berkarbohidrat tinggi. Tepung sukun memiliki cita rasa yang khas dari buah sukun dan kondisi tepung yang lebih baik dibandingkan tepung tapioka. Pemanfaatan tepung sukun menjadi olahan makanan dapat mensubstitusi penggunaan tepung terigu hingga $75 \%$ tergantung jenis produk atau olahan makanan yang dihasilkan (Suyanti et al., 2003). Tujuan dari penelitian ini adalah mengetahui pengaruh substitusi tepung sukun terhadap kandungan gizi, nilai energi, dan organoleptik cookies tepung beras. Manfaat yang diperoleh dari penelitian ini adalah mensubstitusi bahan baku tepung pada pembuatan cookies dan memberikan informasi yang akurat mengenai penggunaan optimal dari tepung sukun untuk substitusi cookies tepung beras.

\section{Materi dan Metode \\ Materi}

Bahan yang digunakan dalam penelitian ini adalah tepung beras, tepung sukun, margarin, gula bubuk, kuning telur, perisa coklat, sampel cookies, katalisator (selenium reagent mixture), aquades, asam borat, $\mathrm{HCl}, \mathrm{H}_{2} \mathrm{SO}_{4}, \mathrm{NaOH}$, metilen red, dan metilen blue, pelarut, air panas, $\mathrm{H}_{2} \mathrm{SO}_{4}$, dan $\mathrm{NaOH}$. Peralatan yang digunakan selama penelitian adalah oven, loyang, baskom, mixer, penggilas adonan, cetakan cookies, timbangan, oven, cawan, timbangan, desikator, labu destruksi, pemanas (kompor gas), labu destilasi, kondensor, buret, pipet tetes, alat ekstrkasi soxhlet, labu ekstraksi, kondensor, penangas air, tanur, erlenmeyer, autoklaf, dan kertas saring.

\section{Metode}

Penelitian dilakukan pada bulan September November 2015. Penelitian meliputi proses pembuatan cookies, analisis kandungan gizi dan uji organoleptik. Penelitian ini dilakukan dengan desain penelitian Rancangan Acak Lengkap (RAL) dengan 6 perlakuan dan 3 kali ulangan dengan mensubstitusi bahan baku tepung. Perlakuan yang diterapkan yaitu cookies tanpa substitusi tepung sukun (T0), cookies dengan substitusi tepung sukun $10 \%$ (T1), cookies dengan substitusi tepung sukun $20 \%$ (T2), cookies dengan substitusi tepung sukun $30 \%$ (T3), cookies dengan substitusi tepung sukun $40 \%$ (T4), dan cookies dengan substitusi tepung sukun $50 \%$ (T5). Analisis kandungan gizi meliputi kadar air metode oven (Legowo dan Nurwantoro, 2004), kadar protein metode Mikro Kjeldhal (Legowo et al, 2005), kadar lemak metode ekstraksi soxhlet (Legowo et al, 2005), kadar karbohidrat metode by difference (Apriyantono et al., 1989), kadar abu (Apriyantono et al., 1989), kadar serat kasar (Apriyantono et al., 1989), dan nilai energi (Almatsier, 2004). Kadar serat kasar dilakukan dengan cara menghidrolisis sampel dengan asam kuat dan basa kuat encer sehingga karbohidrat, protein, dan zatzat lain terhidrolisis lalu larutan disaring dan dicuci dengan air panas yang mengandung asam dan alkohol. Nilai energi dihitung berdasarkan komposisi lemak, protein, dan karbohidrat. Uji organoleptik dilakukan dengan memberi skor pada parameter rasa, rasa coklat, warna, aroma, tekstur, dan kesukaan (Kartika, 1988). Skor penilaian uji organoleptik dapat dilihat pada Tabel 1.

\section{Proses Pembuatan Cookies}

Pembuatan cookies pada penelitian ini dilakukan dengan mengacu pada metode yang dilakukan oleh Fatkurahman et al., 2012 dengan modifikasi. Langkah pertama melakukan penimbangan bahan yaitu tepung beras 100 gram, tepung sukun $(0 \%, 10 \%, 20 \%, 30 \%$, $40 \%$ dan $50 \%$ ), margarin 40 gram, gula bubuk 60 gram, 1 butir kuning telur, susu skim 5 gram, garam 0,5 gram, perisa coklat $1 / 2$ sendok teh, air $15 \mathrm{ml}$ dan baking soda 3 gram. Tepung beras disangrai selama 2-3 menit kemudian tambahkan margarin, gula bubuk, susu skim, dan garam. Dicampur dengan mixer selama 3-7 menit. Ditambahkan air, perisa coklat, dan kuning telur kemudian dicampurkan kembali dengan mixer selama 1-3 menit. Ditambahkan tepung sukun, tepung beras, dan baking soda lalu dicampur menggunakan mixer selama 3-5 menit. Adonan dicetak, diletakkan di dalam loyang dan dipanggang pada suhu $150^{\circ} \mathrm{C}$ selama 15 menit. Cookies yang telah masak diangkat dari oven kemudian didinginkan, dan disimpan dalam toples kedap udara, kemudian di analisis.

\section{Analisis Statistik}

Data yang diperoleh, dianalisis dengan metode One-Way ANOVA dan Kruskal Wallis menggunakan SPSS 16.0. Taraf signifikansi yang ditetapkan sebesar $a=0,05$.

\section{Hasil Dan Pembahasan}

Tepung Beras dan Tepung Sukun

Hasil analisis pada bahan baku dan bahan substitusi pada cookies berupa tepung beras dan tepung sukun (Tabel 2) menunjukkan kadar air dari tepung beras sebesar $12,83 \%$ dan tepung sukun sebesar $8,66 \%$. Kadar air dari tepung beras sesuai dengan SNI 3549-2009 yaitu maksimal 13\%. Kadar abu yang diperoleh tepung beras adalah sebesar 0,22\% dan tepung sukun sebesar $4,24 \%$. Kadar abu menunjukkan besarnya jumlah mineral yang terkandung dalam bahan. Kadar abu pada tepung beras sesuai dengan SNI 3549-2009 yaitu maksimal sebesar $1 \%$. Sesuai dengan pernyataan Andarwulan et al. (2011) yang menyatakan bahwa semakin tinggi kadar abu dalam cookies menandakan tingginya 
kandungan mineral yang terdapat dalam cookies seperti kalsium, kalium, dan besi. Kadar lemak yang diperoleh pada tepung beras adalah sebesar 4,99\% dan tepung sukun sebesar $6,26 \%$. Kadar protein yang diperoleh dari tepung beras adalah sebesar $7,78 \%$ dan tepung sukun sebesar $4,75 \%$. Kadar serat kasar yang diperoleh dari tepung beras adalah sebesar $0,75 \%$ dan tepung sukun sebesar $6,16 \%$.

\section{Kandungan Gizi dan Nilai Energi Cookies}

Kadar air cookies (Tabel 3) menunjukkan bahwa substitusi tepung sukun memberikan pengaruh pada hasil kadar air $(\mathrm{P}<0,05)$. Kadar air cookies dengan substitusi tepung sukun terendah pada perlakuan dengan konsentrasi 10 dan $50 \%$ sebesar $6,55 \%$ dan yang tertinggi adalah pada perlakuan dengan konsentrasi $30 \%$ sebesar $8,33 \%$. Kadar air cookies yang dihasilkan dipengaruhi oleh kadar air dari bahan baku cookies yang berupa tepung beras adalah sebesar $12,83 \%$ dan bahan substitusi cookies berupa tepung sukun yaitu sebesar $8,65 \%$. Menurut Fatkurahman et al. (2012) ada beberapa proses penting selama pemanggangan yaitu pengembangan adonan, koagulasi protein, gelatinisasi pati, dan penguapan air. Proses pemanasan menyebabkan terjadinya proses gelatinisasi pati yang mengakibatkan granula pati membengkak karena adanya penyerapan air. Pembengkakan granula pati terbatas hingga sekitar $30 \%$ dari berat tepung dan apabila pembengkakan granula pati telah mencapai batas, granula pati tersebut akan pecah sehingga terjadi proses penguapan air. Tepung sukun memiliki kadar amilosa sebesar 26,76\% dan kadar amilopektin sebesar $73,24 \%$, sehingga akan mempermudah proses gelatinisasi pati (Setiani et al., 2013).

Kadar protein cookies (Tabel 3) menunjukkan bahwa substitusi tepung sukun memberikan pengaruh pada hasil kadar protein $(P<0,05)$. Kadar protein cookies dengan substitusi tepung sukun terendah pada perlakuan dengan konsentrasi $50 \%$ sebesar $4,88 \%$ dan yang tertinggi adalah pada perlakuan dengan konsentrasi $10 \%$ sebesar $6,09 \%$. Semakin banyak tepung sukun yang ditambahkan cenderung menyebabkan semakin rendahnya kadar protein dari cookies. Sesuai dengan pendapat Sukandar et al. (2014) yang menyatakan bahwa protein yang terkandung dalam tepung sukun memang rendah yaitu sebesar 3,64\%. Menurut Murni et al. (2014) tepung sukun memiliki kadar protein yang lebih rendah dibandingkan dengan tepung terigu yaitu $3,60 \%$ sehingga dengan peningkatan substitusi tepung sukun secara tidak langsung akan menurunkan kadar protein cookies.

Kadar lemak cookies (Tabel 3) menunjukkan bahwa substitusi tepung sukun memberikan pengaruh pada hasil kadar lemak $(\mathrm{P}<0,05)$. Kadar lemak cookies dengan substitusi tepung sukun terendah adalah pada perlakuan dengan konsentrasi $0 \%$ sebesar $14,51 \%$ dan yang tertinggi adalah pada perlakuan dengan konsentrasi $40 \%$ sebesar 16,25\%. Kadar lemak cookies dipengaruhi oleh adanya penambahan margarin dan telur dalam pembuatan cookies. Margarin mengandung sejumlah lipid dan sebagian dari lipid itu terdapat bentuk terikat sebagai lipoprotein dan bila margarin ditambahkan pada adonan, maka adonan tersebut akan memiliki kadar lemak yang tinggi. Sesuai dengan pendapat Oktavia (2008), lemak yang ada pada cookies umumnya berasal dari margarin dan telur. Diperkuat oleh pendapat Lopulalan et al. (2013) yang menyatakan bahwa kadar lemak dalam cookies lebih banyak disumbangkan oleh margarin dan kuning telur. Lemak berfungsi sebagai shortening dan memberikan pengaruh pada teksur sehingga cookies yang dihasilkan menjadi lebih lembut dan lemak dapat memperbaiki struktur fisik seperti pengembangan, kelembutan tekstur, dan aroma.

Kadar karbohidrat cookies (Tabel 3) menunjukkan bahwa substitusi tepung sukun tidak memberikan pengaruh pada hasil kadar karbohidrat $(P>0,05)$. Kadar karbohidrat cookies dengan substitusi tepung sukun terendah adalah pada perlakuan dengan konsentrasi $30 \%$ sebesar $69,11 \%$ dan yang tertinggi adalah pada perlakuan dengan konsentrasi $10 \%$ sebesar $70,50 \%$. Kadar karbohidrat pada cookies dihitung secara by difference dan dipengaruhi oleh komponen nutrisi lain yaitu kandungan protein, lemak, air, dan abu. Sesuai dengan pendapat Fatkurahman et al. (2012) yang menyatakan bahwa kadar karbohidrat dihitung secara by difference dipengaruhi oleh komponen nutrisi lain yaitu protein, lemak, air, dan abu, semakin tinggi komponen nutrisi lain maka kadar karbohidrat semakin rendah dan sebaliknya apabila komponen nutrisi lain semakin rendah maka kadar karbohidrat semakin tinggi. Karbohidrat merupakan sumber kalori utama yang berperan dalam menentukan karakteristik bahan makanan seperti warna, rasa, dan tekstur. Menurut Andarwulan et al. (2011), karbohidrat mengandung gula pereduksi yang berperan dalam reaksi pencoklatan non enzimatis (Maillard) apabila bereaksi dengan senyawa yang memiliki gugus amino seperti protein.

Kadar abu cookies (Tabel 3) menunjukkan bahwa substitusi tepung sukun memberikan pengaruh pada hasil kadar abu $(\mathrm{P}<0,05)$. Kadar abu cookies dengan substitusi tepung sukun terendah adalah pada perlakuan dengan konsentrasi 0 sebesar $1,77 \%$ dan yang tertinggi adalah pada perlakuan dengan konsentrasi $50 \%$ sebesar 2,45\%. Semakin tinggi konsentrasi tepung sukun yang disubstitusikan menghasilkan kadar abu yang semakin tinggi. Besarnya nilai kadar abu cookies dipengaruhi oleh besarnya jumlah mineral yang terkandung dalam bahan. Sesuai dengan pendapat Fatkurahman et al.(2012) yang menyatakan bahwa besarnya kadar abu pada suatu produk pangan bergantung pada besarnya kandungan mineral bahan yang digunakan dan apabila kadar abu melebihi dari standar mutu yang ada maka akan mempengaruhi warna cookies yang dihasilkan. Tepung sukun banyak mengandung mineral seperti kalsium dan fosfor. Sesuai dengan pendapat Sukandar et al. (2014) tepung sukun merupakan tepung bebas gluten yang 
dihasilkan dari buah sukun dan banyak mengandung mineral berupa kalsium dan fosfor.

Kadar serat kasar cookies (Tabel 3) menunjukkan bahwa substitusi tepung sukun memberikan pengaruh pada hasil kadar serat kasar $(P<0,05)$. Kadar serat kasar cookies dengan substitusi tepung sukun terendah adalah perlakuan dengan konsentrasi $0 \%$ sebesar $0,85 \%$ dan yang tertinggi pada perlakuan dengan konsentrasi $50 \%$ sebesar $2,50 \%$. Peningkatan kadar serat kasar pada cookies seiring dengan peningkatan substitusi tepung sukun karena tepung sukun memiliki kadar serat kasar yang lebih tinggi yaitu sebesar 6,1606\%. Semakin tinggi serat yang terkandung maka semakin baik untuk pencernaan. Hal ini sesuai dengan pendapat Lopulalan et al. (2013) yang menyatakan bahwa cookies yang mengandung kadar serat kasar yang tinggi baik bagi tubuh karena serat dapat mengatur terjadinya gerakan usus dan mencegah konstipasi (sulit buang air besar) karena serat memberikan muatan pada sisa makanan yang ada di dalam usus besar. Serat kasar merupakan senyawa yang tidak dapat dicerna oleh organ pencernaan manusia maupun hewan, serta tidak larut dalam asam $\left(\mathrm{H}_{2} \mathrm{SO}_{4}\right)$ maupun basa $(\mathrm{NaOH})$. Menurut Apriyantono et al. (1989), serat kasar merupakan residu bahan makanan setelah mengalami perlakuan dengan asam dan alkali mendidih dan terdiri dari selulosa dengan sedikit lignin dan pentosa.

Nilai energi cookies (Tabel 3) menunjukkan bahwa substitusi tepung sukun memberikan pengaruh pada hasil nilai energi $(P<0,05)$. Niai energi cookies dengan substitusi tepung sukun terendah pada perlakuan dengan konsentrasi $30 \%$ sebesar $433,05 \%$ dan yang tertinggi pada perlakuan dengan konsentrasi $40 \%$ sebesar $444,25 \%$. Nilai energi dapat diperoleh dari karbohidrat, lemak, dan protein yang terkandung dalam cookies tersebut. Hal ini sesuai dengan pernyataan Lopulalan et al. (2013) yang menyatakan bahwa energi dapat diperoleh dari karbohidrat, protein, dan lemak yang terdapat dalam bahan makanan yang disimpan dalam tubuh dan energi bagi manusia digunakan untuk tumbuh dan berkembang. Diperkuat oleh pernyataan Almatsier (2004) yang menyatakan bahwa manusia membutuhkan energi untuk menunjang pertumbuhan, mempertahankan hidup, dan melakukan aktivitas fisik. Cookies biasanya dikonsumsi sebagai camilan atau snack dan kebutuhan energi yang harus dipenuhi saat camilan adalah $20 \%$ dari kebutuhan energi selama satu hari (Almatsier, 2004).

\section{Uji Organoleptik}

Rasa cookies (Tabel 4) menunjukkan rasa yang sangat manis pada konsentrasi $0 \%$ dan yang tidak manis pada konsentrasi 10\%. Tepung sukun memberikan sedikit rasa getir atau pahit disebabkan oleh rasa langu pada tepung sukun tersebut. Menurut Sukandar et al. (2014), senyawa yang menyebabkan timbulnya rasa pahit atau getir adalah kandungan tanin pada buah sukun. Rasa pada cookies juga dipengaruhi oleh penambahan margarin dan telur. Kandungan

Tabel 2. Hasil analisis tepung beras dan tepung sukun

\begin{tabular}{lcc}
\multicolumn{1}{c}{ Analisis } & Tepung Beras & Tepung Sukun \\
\hline Kadar Air & $12,83 \%$ & $8,66 \%$ \\
Kadar Abu & $0,22 \%$ & $4,24 \%$ \\
Kadar Lemak & $4,99 \%$ & $6,26 \%$ \\
Kadar Protein & $7,78 \%$ & $4,75 \%$ \\
Kadar Serat Kasar & $0,75 \%$ & $6,16 \%$ \\
\hline
\end{tabular}

Tabel 3. Kadar air, kadar protein, kadar lemak, kadar karbohidrat, kadar abu, kadar serat kasar, dan nilai energi cookies tepung beras dengan substitusi berbagai konsentrasi tepung sukun

\begin{tabular}{|c|c|c|c|c|c|c|}
\hline \multirow[t]{2}{*}{ Parameter } & \multicolumn{6}{|c|}{ Konsentrasi tepung sukun } \\
\hline & $0 \%$ & $10 \%$ & $20 \%$ & $30 \%$ & $40 \%$ & $50 \%$ \\
\hline Kadar air & $7,92 \pm 0,75^{\mathrm{a}}$ & $6,55 \pm 0,69^{b}$ & $7,44 \pm 0,51^{\mathrm{ab}}$ & $8,33 \pm 0,33^{a}$ & $6,89 \pm 0,19^{b}$ & $6,55 \pm 0,39^{b}$ \\
\hline Kadar protein & $5,57 \pm 0,31^{a b}$ & $6,09 \pm 0,60^{b}$ & $5,78 \pm 0,30^{\mathrm{ab}}$ & $5,26 \pm 0,24^{b c}$ & $5,24 \pm 0,08^{b c}$ & $4,88 \pm 0,18^{c}$ \\
\hline Kadar lema & $14,51 \pm 0,45^{\mathrm{a}}$ & $14,89 \pm 0,26^{a}$ & $14,74 \pm 0,36^{\mathrm{a}}$ & $15,06 \pm 0,34^{\mathrm{ab}}$ & $16,25 \pm 0,54^{c}$ & $15,88 \pm 0,69^{b c}$ \\
\hline Kadar karbohidrat $^{\text {ns }}$ & $70,26 \pm 0,63$ & $70,50 \pm 1,13$ & $69,98 \pm 0,09$ & $69,11 \pm 0,23$ & $69,26 \pm 0,70$ & $70,24 \pm 0,73$ \\
\hline Kadar abu & $1,77 \pm 0,05^{\mathrm{a}}$ & $1,96 \pm 0,04^{b}$ & $2,06 \pm 0,07^{b}$ & $2,23 \pm 0,20^{c}$ & $2,36 \pm 0,05^{\mathrm{cd}}$ & $2,45 \pm 0,03^{d}$ \\
\hline Kadar serat $\mathrm{k}$ & $0,85 \pm 0,02^{a}$ & $1,43 \pm 0,19^{b}$ & $1,99 \pm 0,08^{c}$ & $2,03 \pm 0,04^{c}$ & $2,19 \pm 0,02^{c}$ & $2,50 \pm 0,20^{d}$ \\
\hline Nilai energi & $433,91 \pm 5,24^{\mathrm{ab}}$ & $440,40 \pm 2,98^{\mathrm{bc}}$ & $435,70 \pm 3,69^{a b}$ & $433,05 \pm 3,18^{a}$ & $444,25 \pm 2,41^{c}$ & $443,36 \pm 3,45^{\mathrm{c}}$ \\
\hline
\end{tabular}

ns: non signifikan, notasi yang berbeda pada baris yang sama menunjukkan beda nyata pada $a=0,05$

Tabel 4. Organoleptik rasa, rasa coklat, warna, aroma, tekstur, dan kesukaan cookies tepung beras dengan substitusi berbagai konsentrasi tepung sukun

\begin{tabular}{lcccccc}
\hline \multicolumn{1}{c}{ Parameter } & \multicolumn{5}{c}{ Konsetrasi tepung sukun } \\
\cline { 2 - 7 } Organoleptik $^{n}$ & \multicolumn{1}{c}{$0 \%$} & $10 \%$ & $20 \%$ & $30 \%$ & $40 \%$ & $50 \%$ \\
\hline Rasa $^{\text {ns }}$ & $2,50 \pm 0,51$ & $2,10 \pm 0,55$ & $2,30 \pm 0,73$ & $2,35 \pm 0,59$ & $2,30 \pm 0,80$ & $2,15 \pm 0,81$ \\
Rasa coklat $^{\text {ns }}$ & $2,20 \pm 0,77$ & $1,90 \pm 0,72$ & $2,05 \pm 0,76$ & $2,10 \pm 0,72$ & $2,05 \pm 0,69$ & $1,85 \pm 0,59$ \\
Warna $^{\text {ns }}$ & $2,80 \pm 0,61$ & $2,80 \pm 0,52$ & $3,10 \pm 0,55$ & $2,95 \pm 0,51$ & $2,75 \pm 0,64$ & $2,65 \pm 0,67$ \\
Aroma & $2,15 \pm 0,74^{\text {ac }}$ & $1,65 \pm 0,67^{\mathrm{b}}$ & $1,75 \pm 0,72^{\mathrm{ab}}$ & $2,30 \pm 0,66^{\mathrm{c}}$ & $2,10 \pm 0,79^{\mathrm{abc}}$ & $2,05 \pm 0,76^{\mathrm{abc}}$ \\
Tekstur & $2,05 \pm 0,89^{\mathrm{a}}$ & $2,70 \pm 0,57^{\mathrm{b}}$ & $2,10 \pm 0,85^{\mathrm{a}}$ & $1,95 \pm 0,76^{\mathrm{a}}$ & $2,25 \pm 0,79^{\mathrm{a}}$ & $2,30 \pm 0,66^{\mathrm{a}}$ \\
Kesukaan & $2,90 \pm 0,72^{\mathrm{a}}$ & $2,35 \pm 0,87^{\mathrm{b}}$ & $2,30 \pm 0,66^{\mathrm{b}}$ & $2,15 \pm 0,81^{\mathrm{b}}$ & $1,65 \pm 0,67^{\mathrm{c}}$ & $1,50 \pm 0,69^{\mathrm{c}}$ \\
\hline
\end{tabular}

ns: non signifikan, notasi yang berbeda pada baris yang sama menunjukkan beda nyata pada $a=0,05$ 
lemak dan protein dalam adonan dapat membantu meningkatkan rasa produk yang dihasilkan.

Rasa coklat cookies (Table 4) menunjukkan rasa coklat yang sangat terasa pada konsentrasi $0 \%$ dan yang tidak terasa pada konsentrasi $50 \%$. Adanya rasa coklat pada cookies disebabkan oleh adanya penambahan perisa coklat. Rasa getir pada cookies dengan substitusi tepung sukun dapat ditutupi dengan adanya penambahan perisa coklat. Sesuai dengan pendapat Mileiva (2007) yang menyatakan bahwa perisa coklat sangat tepat digunakan untuk menutupi rasa dan warna menyimpang yang muncul.

Warna cookies (Tabel 4) menunjukkan warna yang coklat keemasan padakonsentrasi $20 \%$ dan yang sangat coklat pada konsentrasi $50 \%$. Semakin tinggi konsentrai tepung sukun yang ditambahkan maka semakin coklat warna cookies yang dihasilkan. Sesuai dengan pendapat Murni et al. (2014) yang menyatakan bahwa semakin banyak tepung sukun yang ditambahkan maka semakin rendah penilaian terhadap warna cookies karena tepung sukun memiliki warna yang agak gelap. Warna yang diihasilkan oleh cookies juga dipengaruhi oleh bahan yang digunakan dalam pembuatan cookies dan karena adanya reaksi Maillard selama proses pemanggangan. Menurut Pato dan Yusmarini (2004), penggunaan suhu tinggi dengan waktu yang lama dapat menyebabkan terjadinya reaksi browning non enzimatik (reaksi Maillard) dan karamelisasi, reaksi Maillard terjadi karena adanya reaksi gugus amino protein dengan gula.

Aroma cookies (Tabel 4) menunjukkan aroma yang sangat harum pada konsentrasi $30 \%$ dan yang tidak harum pada konsentrasi $10 \%$. Aroma yang dipengaruhi oleh aroma khas yang dimiliki oleh tepung sukun. Menurut Murni et al. (2014), aroma yang terdapat pada suatu bahan pangan berasal dari sifat alami bahan tersebut dan ada yang berasal dari berbagai macam campuran bahan penyusunnya. Aroma yang dihasilkan oleh cookies juga ditentukan oleh perpaduan bahan-bahan pembuatan cookies. Menurut Sitohang et al. (2015), bau khas adonan ditimbulkan dari komponen pada adonan seperti pencampuran margarin dan telur, aroma cookies juga dipengaruhi oleh proses pemanggangan.

Tekstur cookies (Tabel 4) menunjukkan tekstur yang sangat renyah pada konsentrasi $10 \%$ dan yang tidak renyah pada konsentrasi $30 \%$. Tekstur pada cookies ditentukan oleh kadar air, jumlah dan kandungan lemak, karbohidrat, dan protein yang menyusunnya serta dipengaruhi oleh semua bahan baku yang digunakan. Tekstur pada cookies substitusi tepung sukun disebabkan oleh tepung sukun mengandung protein dalam jumlah kecil. Menurut Normasari (2010), selain dipengaruhi oleh kandungan protein, tekstur cookies juga dipengaruhi oleh kandungan pati. Air dalam adonan menyebabkan pati mengalami penyerapan air sehingga granula pati akan menggelembung dan jika dipanaskan, pati akan tergelatinisasi kemudian gel pati akan mengalami proses dehidrasi sehingga gel membentuk kerangka yang kokoh.
Kesukaan cookies (Tabel 4) menunjukkan kesukaan yang sangat suka pada konsentrasi $0 \%$ dan yang tidak suka pada konsentrasi $50 \%$. Pengujian kesukaan keseluruhan merupakan penilaian terhadap semua faktor mutu meliputi warna, rasa, aroma, dan tekstur. Semakin besar konsentrasi substitusi tepung sukun akan menurunkan kesukaan secara keseluruhan terhadap cookies tepung beras dengan substitusi tepung sukun yang dihasilkan.

\section{Kesimpulan}

Berdasarkan hasil penelitian analisis kandungan gizi, nilai energi dan uji organoleptik pada cookies tepung beras dengan subtitusi tepung sukun dapat disimpulkan bahwa cookies dengan kadar air, kadar protein, dan kadar karbohidrat terbaik pada konsentrasi $10 \%$, kadar lemak dan nilai energi terbaik pada konsentrasi $40 \%$, kadar abu dan kadar serat kasar terbaik pada konsentrasi $0 \%$. Semakin besar konsentrasi substitusi tepung sukun akan menurunkan kesukaan secara keseluruhan terhadap cookies tepung beras dengan substitusi tepung sukun yang dihasilkan.

\section{Daftar Pustaka}

Andarwulan, N., F. Kusnandar dan D. Herawati. 2011.

Analisis Pangan. Dian Rakyat. Jakarta

Almatsier, S. 2004. Prinsip Dasar IImu Gizi. Gramedia Pustaka Utama. Jakarta.

Apriyantono, A., D. Fardiaz, N.L. Puspitasari, dan S, Budijanto. 1989. Petunjuk Laboratorium Analisis Pangan. IPB-Press, Bogor.

Fatkurahman, R., W. Atmaka dan Basito. 2012. Karakteristik sensoris dan sifat fisikokimia cookies dengan substitusi bekatul beras hitam (Oryza sativa L.) dan tepung jagung (Zea mays L.). Jurnal Teknosains Pangan. 1 (1): 49-57.

Gayati, I.A.P. 2014. Pemanfaatan Tepung Kacang Koro Pedang (Canavalia ensiformis [L.] DC) dan Tepung Mocaf (Modified Cassava Flour) Pada Cookies Ditinjau dari Sifat Fisiko Kimia dan Sensori. Universitas Katolik Soegijapranata. Semarang.

Kartika, B. 1988. Pedoman Uji Inderawi Bahan Pangan. Pusat antar Universitas Pangan dan Gizi UGM, Yogyakarta.

Legowo, A. M., dan Nurwantoro. 2004. Analisis Pangan. Program Studi Teknologi Hasil Ternak. Fakultas Pertanian. Universitas Diponegoro. Semarang.

Legowo, A. M., Nurwantoro, dan Sutaryo. 2005. Analisis Pangan. Badan Penerbit Universitas Diponegoro, Semarang.

Lopulalan, C. G. Ch., M. Mailoa, dan D. R. Sangadji. 2013. Kajian formulasi penambahan tepung ampas tahu terhadap sifat organoleptik dan kimia cookies. Agritekno. 1 (1): 130-138.

Mileiva, S. 2007. Evaluasi Mutu Cookies Garut yang Digunakan pada Program Pemberian Makanan Tambahan (PMT) Untuk Ibu Hamil. Institut Pertanian Bogor. Bogor. 
Murni, T., N. Herawati dan Rahmayuni. 2014. Evaluasi mutu kukis yang disubstitusi tepung sukun (Artocarpus communis) berbasis minyak sawit merah (MSM), tepung temope dan tepung udang rebon (Acetes erythraeus). JOM. 1(1).

Normasari, R. Y. 2010. Kajian Penggunaan Tepung Mocaf (Modified Cassava Flour) Sebagai Substitusi Terigu yang Difortifikasi dengan Tepung Kacang Hijau dan Prediksi Umur Simpan Cookies. Universitas Sebelas Maret. Surakarta.

Oktavia, R. D. 2008. Evaluasi Produk Good Time Cookies di PT. Arnott's Indonesia sebagai Dasar Penentuan Nilai Tambah Produk. Skripsi. Departemen IImu dan Teknologi Pangan Fakultas Teknologi Pertanian Insititut Pertanian Bogor. Bogor.

Pato, U. Dan Yusmarini. 2004. Gizi dan Pangan. UNRI Press. Pekanbaru.

Setiani, W., T. Sudiarti dan L. Rahmidar. 2013. Preparasi dan karakteristik edible film dari poliblend pati sukun-kitosan. Valensi. 3 (2): 100109.

Sitohang, K. A. K., Z. Lubis dan L. M. Lubis. 2015 Pengaruh perbandingan jumlah tepung terigu dan tepung sukun dengan jenis penstabil terhadap mutu cookies sukun. Jurnal Rekayasa Pangan dan Pertanian. 3 (3): 308-315.

SNI (Standar Nasional Indonesia) 3549-2009 tentang Tepung Beras. 2009. Badan Standarisasi Nasional. Jakarta.

Sukandar, D., A. Muawanah, E.R. Amelia, dan W. Basalamah. 2014. Karakteristik cookies berbahan dasar tepung sukun (Artocarpus communis) bagi anak penderita autis. Valensi. 4 (1) : 13-19.

Suyanti, S., Widowati dan Suismono. 2003. Teknologi pengolahan tepung sukun dan pemanfaatannya untuk berbagai produk makanan olahan. Jurnal Warta Penelitian Pengembangan Pertanian. 25 (2): 12-13. 